\section{Influence of Seed Size, Testa Color, Scarification Method, and Immersion in Cool or Hot Water on Germination of Baptisia australis (L.) R. Br. Seeds}

\author{
Thomas H. Boyle ${ }^{1}$ \\ Department of Plant, Soil and Insect Sciences, French Hall, University of \\ Massachusetts, Amherst, MA 01003
}

\section{Kristen Hladun ${ }^{2}$ \\ Plant Biology Graduate Program, Morrill Science Center, University of Massachusetts, Amherst, MA 01003}

Additional index words. germination, native wildflower, propagation, sulfuric acid

\begin{abstract}
A series of experiments was performed to examine the germination responses of Baptisia australis (L.) R. Br. seeds. Germination tests were conducted at $23{ }^{\circ} \mathrm{C}$ and numbers of germinated seed were counted daily for $\mathbf{2 1}$ days. Seeds were separated into two size fractions using standard sieves. Seeds in the large-seeded fraction were heavier than those in the small-seeded fraction, but seed size/weight did not affect the germination percentage at 21 days (G21), the number of days to $50 \%$ of final germination $\left(T_{50}\right)$, or the number of days between $10 \%$ and $90 \%$ germination $\left(T_{90}-T_{10}\right)$. Seeds were classified into two groups based on testa color. Light-brown seeds $(17 \%$ of total) were heavier and had lower G21 and higher $T_{50}$ and $T_{90}-T_{10}$ values than medium- to dark-brown seeds (83\% of total). Seeds scarified mechanically germinated nearly $100 \%$ and had lower $T_{50}$ and $T_{90}-T_{10}$ values than untreated seeds. Untreated seeds had a higher $T_{50}$ value than seeds soaked overnight in $20^{\circ} \mathrm{C}$ water, but the $\mathrm{G} 21$ and $\mathrm{T}_{90}-\mathrm{T}_{10}$ values were similar for the two treatments. Mechanical scarification followed by overnight soaking in $20{ }^{\circ} \mathrm{C}$ water yielded a G21 value of only $12 \%$, and the low germination percentage was attributed to imbibition damage. When seeds were scarified in concentrated $\mathrm{H}_{2} \mathrm{SO}_{4}$ for $0,1,5,20,40$, or $80 \mathrm{~min}, \mathrm{G} 21$ values increased quadratically while $T_{50}$ and $T_{90}-T_{10}$ values decreased quadratically as the immersion time increased. To test the effects of moist heat on germination responses, seeds were immersed for $0,0.5,1,2,4$, or 8 minutes in $85{ }^{\circ} \mathrm{C}$ water. G21 values increased linearly as the immersion period increased from 0 to 2 min but remained similar when the immersion time exceeded $2 \mathrm{~min}$. The duration of immersion in hot water did not affect the $T_{50}$ values whereas $T_{90}-T_{10}$ values decreased linearly as the immersion period increased. We conclude that physical dormancy is responsible for temporal variation in germination of $B$. australis seeds. Scarifying seed in concentrated $\mathrm{H}_{2} \mathrm{SO}_{4}$ for 20 to 80 minutes may be the most practical means of treating bulk lots of $B$. australis seeds to obtain rapid and uniform $(\geq 85 \%)$ germination.
\end{abstract}

Baptisia australis (Fabaceae, subfamily Papilionoideae) is a herbaceous perennial native to rich woods and alluvial thickets from Georgia to Pennsylvania, West Virginia, southern Indiana, and Kentucky (Fernald, 1987). In the northern U.S., plants are 0.6 to $1.2 \mathrm{~m}$ tall and produce terminal racemes of indigo-blue flowers in late May and June (Cumming and Lee, 1960; Nau, 1996). It is a widely cultivated garden plant and is the most common Baptisia species grown as an ornamental (Armitage, 1989).

Baptisia australis is propagated primarily by seed (Nau, 1996). Seeds of B. australis sown in germination trays in a greenhouse without temperature controls in Lexington, Ky. continued to germinate over an eight-year period (Baskin and Baskin, 1998). Dirr (1987)

Received for publication 3 May 2005. Accepted for publication 18 June 2005.

${ }^{1}$ Professor and corresponding author; e-mail tboyle@pssci.umass.edu.

${ }^{2}$ Graduate student. reported $\geq 90 \%$ germination when $B$. australis seeds were collected at maturity and immediately subjected to scarification (mechanical or acid), stratification, or soaking in cold or hot water. Bratcher et al. (1993) obtained 80\% germination for $B$. australis seeds stratified at $5{ }^{\circ} \mathrm{C}$ for 10 weeks, but the germination percentage was only marginally lower (about $70 \%$ ) for nonstratified seeds. The present study was conducted to determine the effects of seed size, seed color, scarification method (mechanical and $\mathrm{H}_{2} \mathrm{SO}_{4}$ ), and immersion in cold or hot water on the germination responses of $B$. australis seeds.

\section{Materials and Methods}

Plant material. Seeds were harvested 1 Oct. 2004 from a field plot of B. australis plants growing at the Univ. of Massachusetts, Amherst, Mass. (lat. $42^{\circ} 22.5^{\prime} \mathrm{N}$ ). All plants in the plot were propagated from seed collected in August 1998 from a single plant growing on the Univ. of Massachusetts campus.
Seeds were cleaned and separated into two size fractions using U.S. standard test sieves. For the large-seeded fraction, $100 \%$ of the seeds passed through a No. 6 sieve $(3.35 \mathrm{~mm}$ nominal opening) and $100 \%$ were retained on a No. 8 sieve ( $2.36 \mathrm{~mm}$ nomimal opening). For the small-seeded fraction, $100 \%$ of the seeds passed through a No. 8 sieve and $100 \%$ were retained on a No. 10 sieve $(2.00 \mathrm{~mm}$ nominal opening). Seeds were stored at $20^{\circ} \mathrm{C}$ and $30 \%$ relative humidity until experiments commenced. Germination experiments were performed between mid-October 2004 and January 2005.

Germination methods. Seeds were sown in $15-\mathrm{cm}$ glass petri dishes on top of a single layer of blue blotter paper (Anchor Paper Co., St. Paul, Minn.). To inhibit fungal growth, seeds were treated one day after sowing with $3 \alpha, 4,7,7 \alpha$-tetrahydro2-[(trichloromethyl)thio]- $1 H$-isoindole$1,3(2 \mathrm{H})$-dione (Captan) at $0.24 \mathrm{mg} / 100 \mathrm{~mL}$ solution. Germination tests were performed in an incubator (model I-35LVL; Percival Scientific, Boone, Iowa) kept at $23 \pm 0.5^{\circ} \mathrm{C}$ with cool-white fluorescent lamps providing $50 \pm 8 \mu \mathrm{mol} \cdot \mathrm{m}^{-2} \cdot \mathrm{s}^{-1}$ photosynthetic photon flux for $12 \mathrm{~h}$ daily. Blotter paper was moistened as needed with deionized water $\left(\mathrm{dH}_{2} \mathrm{O}\right)$. Mechanical scarification was performed by nicking seeds with a razor blade at the end opposite the radicle. Five experiments were conducted. The large-seeded fraction was used in all experiments except Expt. 1, which compared the germination responses of the two size fractions.

Data collection. Four 50-seed replications (plates) were used per treatment. Numbers of germinated seeds (radicle $\geq 1 \mathrm{~mm}$ ) were counted daily for $21 \mathrm{~d}$. Germinated seeds were discarded daily. The germination percentage at $21 \mathrm{~d}(\mathrm{G} 21)$, number of days to $50 \%$ final germination $\left(\mathrm{T}_{50}\right)$, and number of days between $10 \%$ and $90 \%$ germination $\left(\mathrm{T}_{90}-\mathrm{T}_{10}\right)$ were calculated for each treatment. In Expts. 1, 2, and 5 , seeds that had not germinated on day 21 were mechanically scarified on the 21 st day and the final germination percentage was determined $7 \mathrm{~d}$ later $(\mathrm{G} 28) . \mathrm{T}_{50}$ and $\mathrm{T}_{90}-\mathrm{T}_{10}$ values were calculated using data from the first $21 \mathrm{~d}$.

Seed size (Expt. 1). Eight 50-seed replications were collected from the large- and smallseeded fractions. Fresh weights were obtained for each replication and four of the replications were retained for germination studies.

Seed testa color (Expt. 2). Seed testa color was characterized qualitatively with the Royal Horticultural Society (RHS) Colour Chart (RHS, 1966). Seeds of the large-seeded fraction were divided into a light brown group and a medium- to dark brown group. The percentage of light brown seeds in the large-seeded fraction was determined for six 100-seed replications. Seed fresh weight was collected on eight 50 seed replications per color group. Seeds were not separated by color in any of the remaining germination experiments.

Mechanical scarification and soaking in cool water (Expt. 3). Seeds received one of the following four treatments: 1) mechanical scari- 
fication, 2) soaking in $20^{\circ} \mathrm{C} \mathrm{dH_{2 }} \mathrm{O}$ overnight, 3 ) mechanical scarification and soaking in 20 ${ }^{\circ} \mathrm{C} \mathrm{dH_{2 }} \mathrm{O}$ overnight, and 4) untreated control. Acidscarification (Expt. 4). Seeds were immersed for 0 (control), 1, 5, 20, 40, or $80 \mathrm{~min}$ in $18 \mathrm{M}$ (concentrated) sulfuric acid $\left(\mathrm{H}_{2} \mathrm{SO}_{4}\right)$. About 250 seeds were placed in $30 \mathrm{~mL} \mathrm{H}_{2} \mathrm{SO}_{4}$ and stirred with a wooden dowel during the treatment period. Afterwards, seeds (including the control) were rinsed in a stream of tap water for $15 \mathrm{~min}$, dried on a lab bench in glass petri dishes, and sown the following day.

Immersion in hotwater (Expt. 5). Seeds were immersed for 0 (control), $0.5,1,2,4$, or $8 \mathrm{~min}$ in $85 \pm 0.05^{\circ} \mathrm{C}$ tap water. A constant water temperature was attained using a digital-controlled temperature bath (model RTE-140; NESLAB Instruments, Inc., Portsmouth, N.H.). Each 200seed lot that comprised a single treatment was placed in a glass scintillation vial and the top was covered with polypropylene mesh that was secured with fine wire. Vials were filled with water within $2 \mathrm{~s}$ after placement in the water bath. Vials were drained immediately after the appropriate exposure period was completed. Seeds were dried in glass petri dishes and sown the following day.

Data analysis. Data were transformed (arc$\sin$ for $\mathrm{G} 21$ and $\mathrm{G} 28$ and square root for $\mathrm{T}_{50}$ and $\mathrm{T}_{90}-\mathrm{T}_{10}$ ) before analysis. Data were analyzed using the General Linear Models (GLM) or Analysis of Variance (ANOVA) procedure of SAS (SAS Institute, Cary, N.C.). Pooled $t$ tests were used to compare fresh weight values in Expts. 1 and 2. In Expts. 4 and 5, coefficients for linear and quadratic terms were calculated using the Interacting Matrix Programming (IML) software of SAS.

\section{Results and Discussion}

Seed size (Expt. 1). Seeds in the largeseeded fraction were heavier $(P<0.0001)$ than those in the small-seeded fraction. Values for 50 -seed weights were $0.68 \pm 0.01 \mathrm{~g}$ and $0.84 \pm 0.01 \mathrm{~g}$ (mean $\pm \mathrm{SD}$ ) for the small-and large-seeded fractions, respectively. The germination responses, however, were similar for both groups $(P>0.05)$. G21, G28, $\mathrm{T}_{50}$, and $\mathrm{T}_{90}$ $-\mathrm{T}_{10}$ values were $41 \%, 90 \%, 10.3 \mathrm{~d}$, and 14.8 $\mathrm{d}$, respectively, when averaged over the two seed-size fractions.

Seed testa color (Expt. 2). Light-brown seeds ranged from RHS Colour Chart value $164 \mathrm{~A}$ to $165 \mathrm{~B}$ while the medium- to darkbrown seeds ranged from $165 \mathrm{~A}$ to $166 \mathrm{~A} / \mathrm{B}$. Light-brown seeds comprised $17.1 \pm 2.8 \%$ (mean $\pm \mathrm{SD}$ ) of the large-seeded fraction and the remainder $(82.8 \pm 2.8 \%)$ were medium- to dark-brown. Light-brown seeds were significantly $(P<0.0025)$ heavier than the medium- to dark-brown seeds $[0.88 \pm 0.02 \mathrm{~g}($ mean $\pm \mathrm{SD})$ vs. $0.85 \pm 0.01 \mathrm{~g}$, respectively]. In addition, light-brown seeds germinated more slowly $(P<0.0002$ for $\mathrm{G} 21)$ and exhibited greater $\mathrm{T}_{50}$ and $\mathrm{T}_{90}-\mathrm{T}_{10}$ values $(P<0.0005)$ than medium- to dark-brown seeds. $\mathrm{G} 21, \mathrm{~T}_{50}$, and $\mathrm{T}_{90}-\mathrm{T}_{10}$ values were $38 \%, 14.0 \mathrm{~d}$, and 17.0 $\mathrm{d}$ (respectively) for light-brown seeds and were $61 \%, 7.3 \mathrm{~d}$, and $12.5 \mathrm{~d}$ (respectively) for medium- to dark-brown seeds. In contrast, light-brown and medium- to dark-brown seeds showed similar $(P=0.77)$ G28 values, which were $94 \%$ and $95 \%$, respectively.

Arelationship between seed testa color and seed dormancy has been documented in numerous species (Baskin and Baskin, 1998), with darker seeds often displaying greater dormancy than lighter-colored seeds (Debeaujon et al., 2000). Baptisia australis is an exception to this generalization, with lighter-colored seeds showing greater dormancy than darker-colored seeds. Voß et al. (1994) reported a similar phenomenon in B. tinctoria, with light-colored seeds having a slightly greater fresh weight and a lower percentage of imbibed or germinated seeds at $21 \mathrm{~d}$ after sowing than dark-brown seeds. Since the lighter-colored, more dormant seeds were heavier than the darker, less dormant seeds, it seems highly unlikely that a lighter testa color can be attributed to seed immaturity. Further research is needed to determine the mechanism(s) for greater seed dormancy in the lighter-colored seeds.

Fruits (pods) of $B$. australis are 3 to $4 \mathrm{~cm}$ long at maturity and have two rows of anatropous ovules (Fernald, 1987; Wood, 1974). Inspection of pods at seed harvest revealed substantial heterogeneity for testa color within individual pods whereas pods collected at different positions along the raceme exhibited similar patterns of seed color heterogeneity. These observations suggest that heterogeneity for testa color and seed dormancy is established within individual pods and is independent of fruit position within the raceme. Heterogeneity for seed dormancy contributes to temporal variation in germination, which serves a positive role under natural conditions by minimizing risks associated with simultaneous germination for species that occupy habitats subject to droughts, fires, or other natural catastrophes (Baskin andBaskin, 1998). From a horticultural perspective, uniform and rapid germination are desirable attributes and treatments that reduce temporal variation in germination are actively sought.

Mechanical scarification and soaking in cool water (Expt. 3). Mechanically scarified seeds germinated more rapidly than seeds in other treatments and germinated nearly $100 \%$ by day 21 (Table 1, Fig. 1). $\mathrm{T}_{50}$ and $\mathrm{T}_{90}-\mathrm{T}_{10}$ values were significantly lower for mechanically scarified seeds compared to controls. Seeds soaked overnight in $20^{\circ} \mathrm{C}$ water exhibited a lower $\mathrm{T}_{50}$ value than control seeds, but the G21 and $\mathrm{T}_{90}-\mathrm{T}_{10}$ values for the two treatments were

Table 1. Effect of mechanical scarification and immersion in $20^{\circ} \mathrm{C}$ water overnight on the germination responses of Baptisia australis seeds $21 \mathrm{~d}$ after sowing (Expt. 3).

\begin{tabular}{lccr}
\hline Treatment & $\begin{array}{c}\text { Germination } \\
(\%)\end{array}$ & $\begin{array}{c}\mathrm{T}_{50} \\
(\mathrm{~d})\end{array}$ & $\begin{array}{c}\mathrm{T}_{90}-\mathrm{T}_{10} \\
(\mathrm{~d})\end{array}$ \\
\hline Control & $50 \mathrm{~b}^{\mathrm{z}}$ & $10.8 \mathrm{a}$ & $16.0 \mathrm{a}$ \\
Scarified & $96 \mathrm{a}$ & $3.8 \mathrm{c}$ & $4.3 \mathrm{~b}$ \\
Immersed overnight in $\mathrm{H}_{2} \mathrm{O}$ & $51 \mathrm{~b}$ & $7.0 \mathrm{~b}$ & $15.0 \mathrm{a}$ \\
Scarified and immersed overnight & $12 \mathrm{c}$ & $4.3 \mathrm{c}$ & $4.3 \mathrm{~b}$ \\
Significance & $* * *$ & $* * *$ & $* * *$
\end{tabular}

${ }^{z}$ Means followed by different letters indicate significant differences using Tukey's studentized range (HSD) test, $P \leq 0.05$. The HSD was applied to transformed means (arcsin for germination percentage and square root for $\mathrm{T}_{50}$ and $\mathrm{T}_{90}-\mathrm{T}_{10}$ ) and the results presented with the original means.

${ }^{* * * *}$ Significant at $P \leq 0.001$.

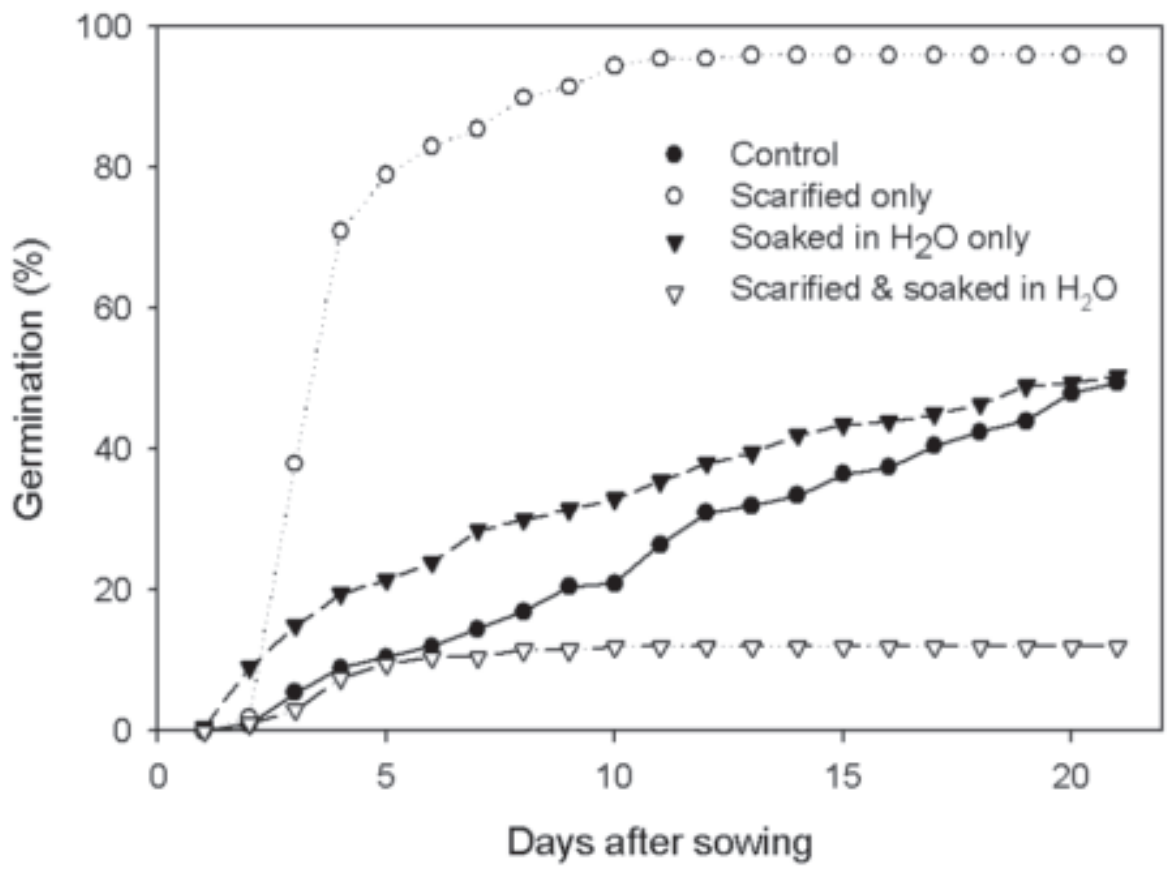

Fig. 1. Influence of mechanical scarification and/or soaking seed overnight in cool $\left(20{ }^{\circ} \mathrm{C}\right) \mathrm{H}_{2} \mathrm{O}$ on the germination percentage of Baptisia australis seeds $21 \mathrm{~d}$ after sowing (Expt. 3). Data are means of four 100 -seed replications. 
similar (Table 1, Fig. 1). Mechanical scarification followed by an overnight soaking in 20 ${ }^{\circ} \mathrm{C}$ water yielded a low germination percentage (Table 1, Fig. 1).

Scarifying the testa before imbibing seeds in water was detrimental to germination, and likely due to imbibition damage. An intact testa acts as a barrier to diffusion and thus restricts water uptake. Removal or injury to the testa permits an increased velocity of water uptake in the outer cells of the cotyledons, resulting in membrane damage to cotyledonary cells and solute leakage from the embryos (Bewley and Black, 1978; Powell, 1998). Imbibition damage has been reported in several other legumes following injury or removal of the testa (Pollock and Toole, 1966; Powell, 1998; Powell and Matthews, 1978).
Acid scarification (Expt. 4). The duration of immersion in $\mathrm{H}_{2} \mathrm{SO}_{4}$ had a significant $(P<$ 0.0001 ) effect on the $\mathrm{G} 21, \mathrm{~T}_{50}$, and $\mathrm{T}_{90}-\mathrm{T}_{10}$ values. G21 values increased quadratically whereas $T_{50}$ and $T_{90}-T_{10}$ values decreased quadratically as the duration of exposure to $\mathrm{H}_{2} \mathrm{SO}_{4}$ increased from 0 to 8 min (Fig. 2).

Mechanical or acid scarification has been reported to enhance germination of Baptisia species other than B. australis. Thetford (1999) examined the germination responses in $B$. hirsuta and found that, at $21 \mathrm{~d}$ after sowing, mechanical scarification yielded $75 \%$ germination while seeds scarified for 15 to $25 \mathrm{~min}$ in $\mathrm{H}_{2} \mathrm{SO}_{4}$ had only about $10 \%$ germination. Mechanical scarification yielded rapid and uniform $(>90 \%)$ germination in B. leucantha (Voigt, 1977) and B. tinctoria (Voß et al.,
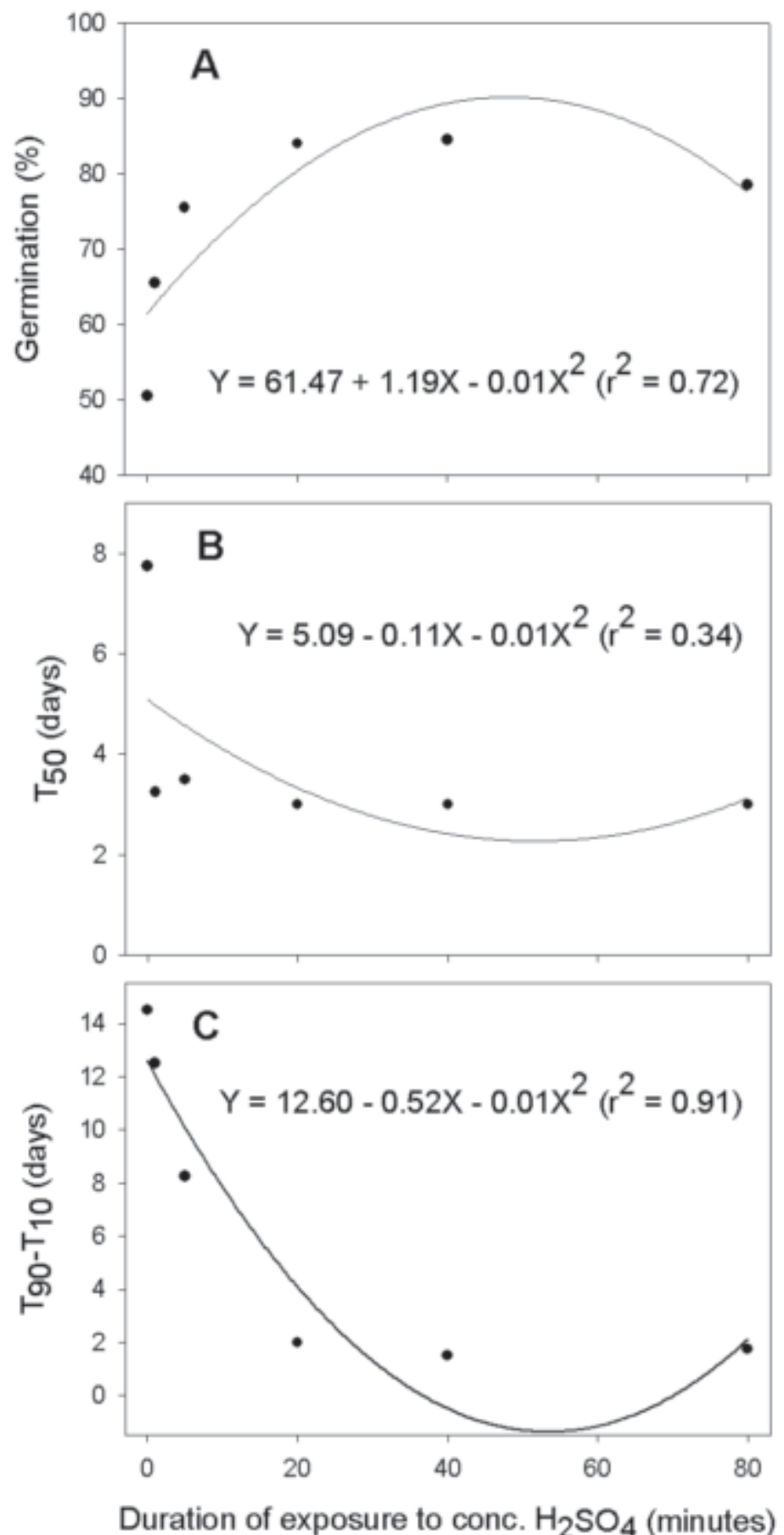

1994). Similar results were obtained in the current experiments, with mechanical scarification yielding $96 \%$ germination and a low (4.3 d) $\mathrm{T}_{90}-\mathrm{T}_{10}$ value. Acid scarification was considerably more effective with $B$. australis (Fig. 2) than with B. hirsuta (Thetford, 1999). Seed testa thickness may vary between species and may also vary according to environmental conditions during seed maturation. Hence, we would expect considerable variation among species (and also among seed lots within species) for the duration of acid treatment that elicits maximum germination.

Immersion in hot water (Expt. 5). G21 values increased linearly as the immersion period in $85^{\circ} \mathrm{C}$ water increased from 0 to 2 min but remained similar when the exposure period was extended from 2 to $8 \mathrm{~min}$ (Fig. $3 \mathrm{~A})$. The period of immersion did not affect the $\mathrm{T}_{50}(P=0.88)$ or $\mathrm{G} 28(P=0.14)$ values. However, $\mathrm{T}_{90}-\mathrm{T}_{10}$ values decreased linearly as the immersion period was increased (Fig. 3B). The $\mathrm{G} 28$ and $\mathrm{T}_{50}$ values were $87.9 \%$ and 11.0 $\mathrm{d}$ when averaged over all treatments.

Thetford (1999) placed B. hirsuta seeds in boiling water which was allowed to cool to room temperature over the following $24 \mathrm{~h}$; seeds were sown the following day and $19 \%$ germinated by day 21 . Immersing $B$. australis seeds in $85^{\circ} \mathrm{C}$ water for 2 to $8 \mathrm{~min}$ yielded markedly higher germination percentages (Fig. 3) than Thetford (1999) obtained with treating $B$. hirsuta seeds with boiling water. Differences between $B$. australis and $B$. hirsuta in seed testa thickness may account for the differential germination responses of these two species to moist heat. Lack of treatment differences for G28 values in Expt. 5 indicates that immersion in $85^{\circ} \mathrm{C}$ water for up to $8 \mathrm{~min}$ did not affect seed viability.

With $B$. australis, moist heat for 2 to 8 min (Fig. 3) was slightly less effective than acid scarification for 20 to $80 \mathrm{~min}$ (Fig. 2) and moderately less effective than mechanical scarification (Fig. 1). From a horticultural perspective, acid scarification for $20 \mathrm{~min}$ elicited slightly greater germination $(84 \%)$ than the most effective $(8 \mathrm{~min})$ moist heat treatment $(\mathrm{G} 21=74 \%)$ (Figs. 2 and 3). However, seeds scarified in $\mathrm{H}_{2} \mathrm{SO}_{4}$ for 20 min germinated more uniformly than seeds dipped in $85^{\circ} \mathrm{C}$ water for $8 \min \left(\mathrm{T}_{90}-\mathrm{T}_{10}=2.0\right.$ vs. $13.0 \mathrm{~d}$, respectively).

These experiments demonstrate that untreated seeds of $B$. australis germinate over a prolonged interval. Softening the seed coat by soaking in $85{ }^{\circ} \mathrm{C}$ water or scarifying the seed coat mechanically or chemically markedly enhanced germination (Figs. 1, 2, and 3). The high $\mathrm{G} 21$ and low $\mathrm{T}_{50}$ and $\mathrm{T}_{90}-\mathrm{T}_{10}$ values exhibited by mechanically scarified seeds (Table 1) indicate that cold stratification is not a requirement for uniform and rapid

Fig. 2. Influence of treatment duration of acid scarification on (A) the germination percentage at $21 \mathrm{~d}$ after sowing, (B) days to $50 \%$ of final germination $\left(\mathrm{T}_{50}\right)$, and $(\mathbf{C})$ days between $10 \%$ and $90 \%$ germination $\left(\mathrm{T}_{90}-\mathrm{T}_{10}\right)$ for Baptisia australis seed (Expt. 4). Data are means of four 100 -seed replications. 

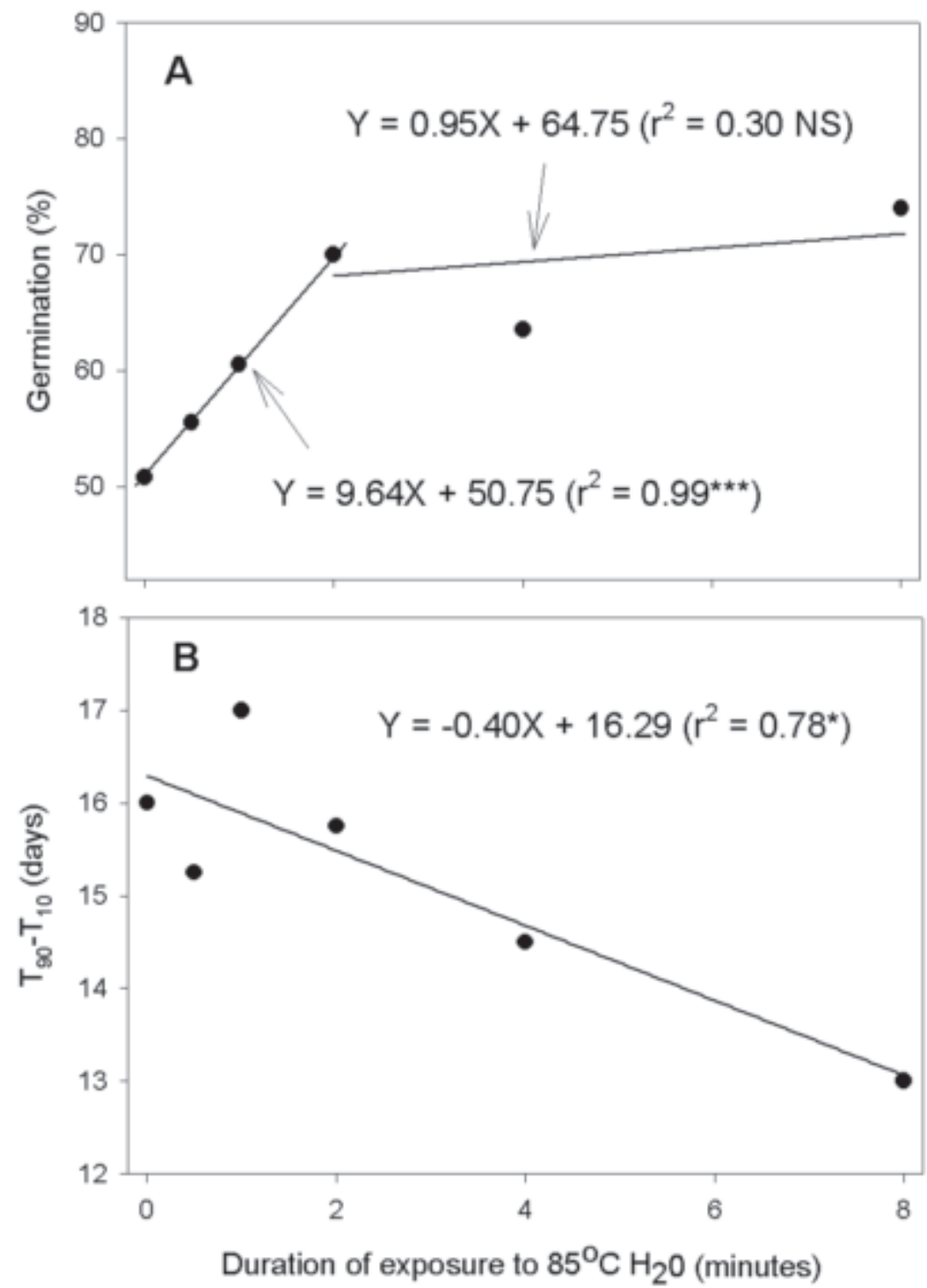

Fig. 3. Effects of immersing Baptisia australis seeds in hot $\left(85^{\circ} \mathrm{C}\right) \mathrm{H}_{2} \mathrm{O}$ for various intervals on the (A) germination percentage at $21 \mathrm{~d}$ after sowing, and (B) days between $10 \%$ and $90 \%$ germination $\left(\mathrm{T}_{90}\right.$ $\left.-\mathrm{T}_{10}\right)$ (Expt. 5). Data are means of four 100-seed replications.

germination. Lack of a stratification requirement indicates that $B$. australis seeds do not exhibit physiological dormancy, in which poor germination is attributed to transitory physiological conditions within the mature embryo (Baskin and Baskin, 1998; Baskin and Baskin, 2004). Our findings help explain the results of Bratcher et al. (1993), who obtained a marginal $(10 \%)$ increase in the germination percentage when $B$. australis seeds were stratified at $5^{\circ} \mathrm{C}$ for 10 weeks.
1) test B. australis seeds from diverse sources to determine their responses to acid scarification and 2) extend these studies to other Baptisia species with ornamental value.

\section{Literature Cited}

Armitage,A.M. 1989. Herbaceous perennial plants: a treatise on their identification, culture, and garden attributes. Varsity Press, Inc., Athens, Ga.

Baskin, C.C. and J.M. Baskin. 1998. Seeds: Ecology, biogeography, and evolution of dormancy and germination. Academic Press, San Diego.

Baskin, J.M. and C.C. Baskin. 2004 A classification system for seed dormancy. Seed Sci. Res. 14:1-16.

Baskin, J.M., C.C. Baskin, and X. Li. 2000. Taxonomy, anatomy and evolution of physical dormancy in seeds. Plant Species Biol. 15:139-152.

Bewley, J.D. and M. Black. 1978. Physiology and biochemistry of seeds in relation to germination. I. Development, germination, and growth. Springer-Verlag, Berlin.

Bratcher, C.B., J.M. Dole, and J.C. Cole. 1993. Stratification improves seed germination of five native wildflower species. HortSci. 28:899-901.

Cumming, R.W. and R.E. Lee. 1960. Contemporary perennials. MacMillan Co., New York.

Debeaujon, I., K.M. Léon-Kloosterziel, and M. Koornneef. 2000. Influence of the testa on seed dormancy, germination, and longevity in Arabadopsis. Plant Physiol. 122:403-413.

Dirr, M.A. 1987. Baptisia australis. Amer. Nurseryman 165(5):166.

Fernald, M.L. 1987. Gray's manual of botany. 8th ed. Dioscorides Press, Portland, Ore.

Nau, J. 1996. Ball perennial manual: Propagation and production. Ball Publishing, Batavia, Ill.

Pollock, B.M. and V.K. Toole. 1966. Imbibition period as the critical temperature sensitive stage in germination of lima bean seeds. Plant Physiol. 41:221-229.

Powell, A.A. 1998. Seed improvement by selection and invigoration. Sci. Agr. 55(Spec. No.):126-133.

Powell, A.A. and S. Matthews. 1978. The damaging effect of water on dry pea embryos during imbibition. J. Expt. Bot. 29:1215-1229.

Royal Horticultural Society. 1966. Royal Horticultural Society colour chart. Royal Hort. Soc., London.

Thetford, M. 1999. Influence of scarification treatments on the germination of hairy wild indigo. S. Nurserymen's Assn. Res. Conf. 44:322-326.

Voigt, J.W. 1977. Seed germination of true prairie forbs. J. Range. Mgt. 30:439-441.

Voß, K., G. Harnischfeger, R. Lieberei, and G. Mevenkamp. 1994. Seed germination behaviour of Baptisia tinctoria (L.) R. Br. Angew. Bot. 68:53-59.

Wood, Jr., C.E.. 1974. A student's atlas of flowering plants: Some dicotyledons of eastern North America. Harper \& Row, New York. 